\title{
Analisis Tax Awareness Dalam Upaya Meningkatkan Kepatuhan Wajib Pajak Di Kantor Pelayanan Pajak Pratama Bekasi Barat
}

\author{
Nunung Latofah ${ }^{\mathrm{a}, 1, *}$, Dwikora Harjo ${ }^{\mathrm{b}, 2}$ \\ a,b Ilmu Administrasi Publik, Institut Ilmu Sosial dan Manajemen STIAMI \\ ${ }^{1}$ nununglatofah1@gmail.com *; ${ }^{2}$ joni.dwikora@gmail.com \\ * corresponding author
}

\section{ARTICLE INFO}

Keywords

Tax Awareness;

Taxpayer Compliance

\begin{abstract}
The phenomenon in this study is the low awareness of taxpayers in carrying out their obligations to pay taxes due to public ignorance of the concrete form of the benefits of money they pay for taxes and the low level of trust of taxpayers which raises the perception that the taxes they pay must be misused. The purpose of this study was to determine the tax awareness in an effort to increase taxpayer compliance at the West Bekasi Tax Office for the period 2017-2019, the obstacles found in the field, and the efforts made by West Bekasi Tax Office to overcome them. This research is a descriptive study using a qualitative approach. The collected data were analyzed using qualitative data analysis methods. The research location was the West Bekasi Primary Tax Office. The results of this study indicate that the steps to increase tax awareness among taxpayers registered at the West Bekasi Primary Tax Office during the 2017-2019 period was not successful. This can be seen from the realization of the 2019 tax revenue which did not reach the target $(97.05 \%)$ even though that year the tax revenue target was lowered from the previous year. Likewise, while taxpayer compliance in paying certain KJS (Deposit Type Code) increased in 2017-2019, tax revenue had still not reached the predetermined target every year
\end{abstract}

\section{PENDAHULUAN}

Negara Republik Indonesia adalah Negara hukum berdasarkan Pancasila dan Undang-Undang Dasar 1945 yang menjunjung tinggi hak dan kewajiban warga negara. Salah satu kewajiban warga Negara adalah membayar pajak seperti terdapat dalam Undang-Undang 1945 Pasal 23a yang berbunyi: "Pajak dan pungutan lain yang bersifat memaksa untuk keperluan Negara diatur dengan Undang-Undang”.

Pajak merupakan sumber utama pendapatan negara dalam pembiayaan pemerintah dan pembangunan. Indonesia mengandalkan beberapa sektor seperti penerimaan negara yang bersumber dari pajak, penerimaan bukan pajak, hingga penerimaan yang berasal dari pinjaman atau bantuan luar negeri. Namun salah satu yang menjadi sumber pendapatan terbesar adalah penerimaan dari sektor pajak, sehingga jumlah penerimaan pajak yang sudah ditargetkan perlu dioptimalkan.

Berdasarkan data laporan kinerja pemerintahan Kementerian Keuangan kontribusi pendapatan terbesar dari sektor perpajakan menyumbang 86,5\% untuk APBN 2019 dan sisanya dari PNBP dan Dana Hibah. Kontribusinya terhadap penerimaan negara kian vital karena pajak menjadi sumber penghasilan negara untuk membiayai semua pengeluaran, termasuk pengeluaran pembangunan. Realisasi penerimaan pajak adalah jumlah realisasi penerimaan pajak netto terhadap target penerimaan pajak.

Dalam tercapainya penerimaan pajak, Direktorat Jenderal Pajak melakukan reformasi perpajakan. Selain untuk meningkatkan penerimaan pajak, alasan dilakukannya reformasi perpajakan yaitu untuk meningkatkan kesadaran dan kepatuhan wajib pajak. Salah satu upaya Direktorat Jenderal Pajak dalam melakukan reformasi perpajakan yaitu melakukan pemenuhan kewajiban perpajakan dengan menggunakan sistem daring (dalam jaringan) atau online. Sistem pelayanan pajak yang dibuat secara online atau yang disebut dengan administrasi digitalisasi perpajakan ditujukan untuk meningkatkan pelayanan kepada wajib pajak sehingga diharapkan dapat meningkatkan kepatuhan wajib pajak. Administrasi digitalisasi perpajakan yang sudah berjalan antara lain yaitu $e$ - registration, e-faktur, $e$-filing, $e$-form, dan $e$-billing. Layanan $e$-registration yaitu 
pendaftaran wajib pajak untuk mendapatkan NPWP secara online. Layanan e-faktur yaitu pembuatan faktur pajak secara elektronik. Layanan $e$-filing yaitu pelaporan SPT secara online. Layanan $e$ - form yaitu formulir SPT secara elektronik yang dapat diisi secara offline dan kemudian mengunggah SPT tersebut secara online. Dan Layanan e-billing adalah metode untuk pembayaran pajak secara online maupun melalui atm dengan memasukkan kode billing yang akan diterima oleh Wajib Pajak.

Sistem Perpajakan di Indonesia menerapkan sistem self assessment, yaitu sebuah sistem dimana wajib pajak diberikan kepercayaan dan tanggung jawab untuk berinisiatif untuk mendaftarkan dirinya, melakukan proses penghitungan pajak terhutang, melaporkan jumlah pajak terhutang hingga membayarkan pajak terhutang atas dirinya. Oleh karena itu, pemerintah memberikan pengertian kepada masyarakat tentang betapa pentingnya kesadaran dan pemahaman mengenai pajak bagi kelangsungan pembangunan nasional dan pembiayaan negara.

Namun, yang terjadi sistem self assessment ini masih ada wajib pajak yang tidak melaksanakan kewajiban perpajakannya dengan baik karena kelalaian, kesengajaan, atau ketidaktahuan para wajib pajak atas kewajiban perpajakannya, sehingga menyebabkan pelanggaran-pelanggaran yang dilakukan wajib pajak dalam melakukan kewajiban perpajakannya. Dalam kondisi tersebut keberadaan sistem Self assesment memungkinkan wajibpajak untuk tidak patuh dalam memenuhi kewajiban perpajakan.

Peran serta wajib pajak sangat menentukan tercapainya rencana penerimaan pajak. Namun, dalam prakteknya seringkali di jumpai adanya wajib pajak yang kurang atau tidak mempunyai kesadaran dalam melaksanakan kewajiban perpajakan dengan benar dan bahkan melakukan upaya penghindaraan pajak ( $\operatorname{tax}$ avoidance), sehingga hal tersebut berpengaruh terhadap penurunan tingkat kepatuhan wajib pajak dan penerimaan negara berkurang. Kurangnya kemauan membayar pajak antara lain hasil pemungutan pajak tersebut tidak secara langsung dapat dirasakan oleh wajib pajak. Hal ini terjadi karena masyarakat tidak mengetahui wujud konkret imbalan dari uang yang dikeluarkan untuk membayar pajak. Masyarakat akan lebih cenderung untuk memenuhi kebutuhan pokoknya terlebih dahulu daripada memenuhi kewajiban perpajakannya.

Fenomena yang terjadi dari data tersebut membuktikan bahwa masih ada wajib pajak yang belum patuh dalam melaksanakan kewajiban perpajakannya dalam hal membayar pajak. Ketidakpatuhan wajib pajak ini disebabkan masihrendahnya kesadaran wajib pajak untuk membayar pajak. Karena membayar pajak bukanlah merupakan tindakan yang semudah dan sesederhana untuk mendapatkan sesuatu (konsumsi) bagi masyarakat, tetapi di dalam pelaksanaannya penuh dengan hal yang bersifat emosional. Pada dasarnya tidak seorangpun menikmati kegiatan membayar pajak seperti menikmati kegiatan belanja. Di samping itu potensi bertahan untuk tidak membayar pajak sudah menjadi taxpayers behavior. Maka dari itu kesadaran Wajib Pajak dalam membayar pajak merupakan faktor terpenting. Kesadaran wajib pajak berpengaruh terhadap kepatuhan. Semakin tinggi tingkat kesadaran wajib pajak maka kepatuhan wajib pajak dalam melaksanakan kewajiban perpajakannya yaitu membayar pajak akan meningkat dan penerimaan pajak akan tercapai. (Siti Kurnia Rahayu, 2010). Berdasarkan fenomena di atas maka peneliti tertarik untuk melakukan penelitian dengan judul "Analisis Tax Awareness Dalam Upaya Meningkatkan Kepatuhan Wajib Pajak Di Kantor Pelayanan Pajak Pratama Bekasi Barat"

Sehingga peneliti memberikan batasan-batasan terhadap apa yang akan diteliti lebih lanjut. Adapun yang di bahas pada penelitian ini mengenai tax awareness (kesadaran wajib pajak) dalam upaya meningkatkan kepatuhan wajib pajak serta hambatan dan upaya yang dilakukan Kantor Pelayanan Pajak (KPP) Pratama Bekasi Barat Tahun 2017-2019. Tujuan Penelitian sebagai berikut:

1. Untuk mengetahui dan menganalisis tax awareness (kesadaran wajib pajak) dalam upaya meningkatkan kepatuhan wajib pajak di KPP Pratama Bekasi Barat periode 2017-2019.

2. Untuk mengetahui dan menganalisis.yang menjadi hambatan tax awareness (kesadaran wajib pajak) dalam upaya meningkatkan kepatuhan wajib pajak di KPP Pratama Bekasi Barat periode 2017-2019.

3. Untuk mengetahui dan menganalisis upaya yang dilakukan untuk mengatasi hambatan tax awareness (kesadaran wajib pajak) dalam upaya meningkatkan kepatuhan wajib pajak di KPP Pratama Bekasi Barat periode 2017-2019.

\section{KAJIAN LITERATUR}

Di dalam kajian pustaka ini akan disajikan mengenai teori-teori yang berhubungan dengan penelitian sesuai dengan pokok permasalahan yang ada.

Nunung Latofah, et.al (Analisis Tax Awareness Dalam Upaya Meningkatkan Kepatuhan Wajib Pajak Di Kantor Pelayanan ...) 


\section{1) Teori Administrasi}

a) Administrasi

Menurut Sondang P. Siagian (Inu Kencana Inu Kencana Syafiie, 2010:14) Administrasi adalah keseluruhan proses pelaksanaan dari keputusan-keputusan yang telah diambil dan pelaksanaan itu pada umumnya dilakukan oleh dua orang manusia atau lebih untuk mencapai tujuan yang telah ditentukan sebelumnya.

b) Administrasi Publik

Menurut Rosenbloom (Pasolong, 2010:8) Administrasi Publik adalah pemanfaatan teori-teori dan proses-proses manajemen, politik dan hukum untuk memenuhi keinginan pemerintah dibidang legislatif, dalam rangka fungsi pengaturan dan pelayanan masyarakat secara keseluruhan atau sebagian.

c) Administrasi Pajak

Menurut Pohan (2014:80-90), bahwa Administrasi Pajak dalam arti sempit adalah Merupakan pelayanan dan kegiatan-kegiatan ketatausahaan mencakup kegiatan catat-mencatat dan pembukuan ringan (recording), korespondensi (correspondence), kesekretariatan (secretariate), penyusunan laporan (reporting) dan kearsipan (filing) terhadap kewajiban-kewajiban dan hak- hak wajib pajak, baik dilakukan fiskus maupun dikantor wajib pajak.

\section{2) Teori Pajak}

a) Pajak

Menurut Adriani (Dwikora Harjo, 2019:4), pajak adalah iuran kepada Negara(yang dapat dipaksakan) yang terutang oleh yang wajib membayarnya menurut peraturan- peraturan, dengan tidak mendapatkan prestasi kembali, yang langsung dapat ditunjuk, dan yang gunanya adalah untuk membiayai pengeluaran-pengeluaran umum berhubungan dengan tugas Negara yang menyelenggarakan pemerintahan.

b) Fungsi Pajak

Menurut Anwar (2014:9) mengatakan bahwa dalam pajak terkandung fungsi diantaranya :

(1) Fungsi Budgetair ( Sumber keuangan Negara)

Fungsi budgetair disebut dengan fungsi utama pajak atau fungsi fiskal, yaitu suatu fungsi di mana pajak dipergunakan sebagai alat untuk memasukan dana secara optimal ke kas negara berdasarkan undang-undang yang berlaku.

(2) Fungsi Regulered (Mengatur)

Fungsi regulerend disebut juga sebagai fungsi tambahan bagi pajak, yaitu suatu fungsi dalam mana pajak dipergunakan sebagai alat untuk mencapai tujuan tertentu.

\section{3) Tax Awareness (Kesadaran Wajib Pajak)}

Kesadaran merupakan unsur dalam diri manusia untuk memahami realitas dan bagaimana mereka bertindak atau bersikap terhadap realitas. Secara harfiah, kesadaran sama artinya dengan mawas diri (awareness). Kesadaran juga bisa diartikan sebagai kondisi dimana seorang individu memiliki kendali penuh terhadap stimulus internal maupun stimulus eksternal. Namun, kesadaran juga mencakup dalam persepsi dan pemikiran yang secara samar-samar disadari oleh individu sehingga akhirnya perhatiannya terpusat.

Menurut Rahayu (2010) Kesadaran memenuhi kewajiban perpajakan tidak hanya tergantung kepada masalah-masalah teknis saja yang menyangkut metode 
Pemungutan, tarif pajak, teknis pemeriksaan, penyidikan, penerapan sanksi sebagai perwujudan pelaksanaan ketentuan peraturan perundang-undangan perpajakan, dan pelayanan kepada Wajib Pajak selaku pihak pemberi dana bagi negara. Di samping itu juga tergantung pada kemauan Wajib Pajak sejauh mana Wajib Pajak tersebut akan mematuhi ketentuan peraturan perundang-undanganperpajakan.

Menurut Rahayu (2010) Membayar pajak bukanlah merupakan tindakan yang semudah dan sesederhana untuk mendapatkan sesuatu (konsumsi) bagi masyarakat, tetapi di dalam pelaksanaannya penuh dengan hal yang bersifat emosional. Pada dasarnya tidak seorangpun menikmati kegiatan membayar pajak seperti menikmati kegiatan belanja. Di samping itu potensi bertahan untuk tidak membayar pajak sudah menjadi taxpayers behavior. Maka dari itu kesadaran Wajib Pajak dalam membayar pajak merupakan faktor terpenting. Kesadaran Wajib Pajak berpengaruh terhadap kepatuhan. Semakin tinggi tingkat kesadaran Wajib Pajak maka kepatuhan Wajib Pajak dalam melaksanakan kewajiban perpajakannya akan meningkat dan penerimaan pajak akan tercapai. Menurut Rahayu (2010) ada beberapa indikator dalam mengukur tingkat tax awareness (kesadaran wajib pajak) yaitu:

a) Kesadaran akan fungsi pajak

b) Kesadaran untuk membayar pajak bukan karena paksaan

c) Kesadaran akan manfaat pajak yang dibayarkan

d) Kesadaran bahwa pajak diatur Undang-Undang

\section{4) Kepatuhan}

Menurut Machfud Sidik (Rahayu, 2010:19), Kepatuhan adalah adalah tulang punggung sistem self assesment, dimana wajib pajak bertanggungjawab menetapkan sendiri kewajiban perpajakan dan kemudian secara akurat dan tepat waktu membayar dan melaporkan pajaknya tersebut.

\section{5) Wajib Pajak}

Menurut Rahman (2010:32), Wajib Pajak sering disingkat dengan sebutan WP, adalah orang pribadi atau badan yang menurut ketentuan peraturan perundang-undangan perpajakan ditentukan untuk melakukan kewajiban perpajakan, termasuk pemungut pajak atau pemotong pajak tertentu. Wajib pajak bisa berupa Wajib Pajak Orang pribadi Atau Wajib Pajak Badan. Wajib Pajak Orang Pribadi adalah setiap orang pribadi yang memiliki penghasilan diatas pendapatan tidak kena pajak.

\section{Kerangka Konseptual}

Peran serta wajib pajak sangat menentukan tercapainya rencana penerimaan pajak. Namun, dalam prakteknya seringkali di jumpai adanya wajib pajak yang kurang atau tidak mempunyai kesadaran dalam melaksanakan kewajiban perpajakan dengan benar dan bahkan melakukan upaya penghindaraan pajak ( $\operatorname{tax}$ avoidance), sehingga hal tersebut berpengaruh terhadap penurunan tingkat kepatuhan wajib pajak dan penerimaan negara berkurang. Maka membuat pemerintah dalam hal ini KPP Pratama Bekasi Barat harus melakukan analisis tax awareness (kesadaran wajib pajak) dalam upaya meningkatkan kepatuhan wajib pajak. Dalam penelitian ini, penulis menggunakan ukuran tingkat kesadaran wajib pajak menurut Rahayu (2010) yang dapat diketahui melalui beberapa indikator antara lain : Kesadaran akan fungsi pajak, Kesadaran untuk membayar pajak bukan karena paksaan, Kesadaran akan manfaat pajak yang dibayarkan, dan Kesadaran bahwa pajak diatur undang-undang.

Alasan memakai teori Rahayu dengan keempat ukuran tingkat kesadaran wajib pajak tersebut nantinya dapat diketahui sehingga bisa menganalisis hambatan-hambatan apa saja yang terjadi dalam analisis tax awareness (kesadaran wajib pajak) dalam upaya meningkatkan kepatuhan wajib pajak di Kantor Pajak Pratama Bekasi Barat serta upaya yang dilakukan KPP Pratama Bekasi Barat untuk dapat meningkatkan kepatuhan wajib pajak.

Sehingga berdasarkan kajian literatur dan kerangka konseptual tersebut maka masalah penelitian ini dapat disajikan melalui model atau suatu gambar yang mendeskripsikan entitas yang saling membentuk secara simultan dari fenomena sosial yang di teliti, yaitu sebagai berikut: 


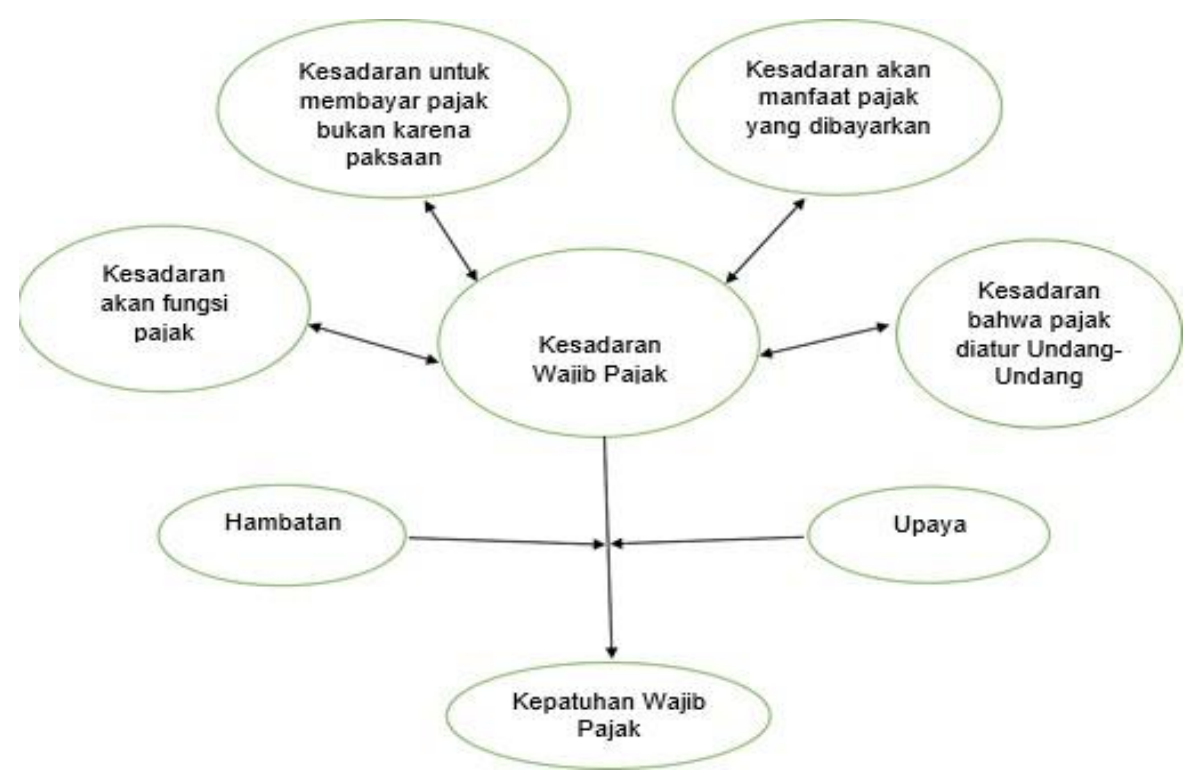

Gambar 1. Model Konseptual

Sumber: Siti Kurnia Rahayu (2010) data diolah penulis

\section{METODE PENELITIAN}

\section{Pendekatan dan Jenis Penelitian}

Pendekatan penelitian yang digunakan oleh penulis adalah pendekatan kualitatif dan jenis penelitian deskriptif untuk memudahkan gambaran secara objektif mengenai Analisis Tax Awareness Dalam Upaya Meningkatkan Kepatuhan Wajib Pajak Di Kantor Pelayanan Pajak Pratama Bekasi Barat. Serta kendala dan upaya yang dilakukan Kantor Pelayanan Pajak Pratama Bekasi Barat dalam upaya meningkatkan kepatuhan wajib pajak di Kantor Pelayanan Pajak Pratama Bekasi Barat

\section{Teknik Pengumpulan Data}

Teknik pengumpulan data merupakan langkah yang paling strategis dalam penelitian, karena tujuan utama dari penelitian adalah mendapatkan data (Sugiyono, 2017:224). Teknik pengumpulan data yang digunakan dalam penelitian ini, yaitu: wawancara, observasi dan dokumentasi. Teknik pengumpulan data menurut cara perolehannya dalam penelitian ini adalah data primer dan data sekunder. Data primer adalah data yang dikumpulkan oleh penelitian langsung dari sumber pertama di lokasi penelitian. Sedangkan data sekunder adalah data yang dikumpulkan oleh organisasi yang telah disahkan atau telah dipublikasikan.

\section{Teknik Analisis Data}

Teknik analisis data yang digunakan dalam penelitian ini adalah deskriptif kualitatif. Analisis data dalam penelitian kualitatif merupakan tahapan yang terdiri dari kegiatan sistematis untuk membangun kaitan data penelitian dalam upaya membentuk makna yang akan dipakai untuk menjawab pertanyaan penelitian. Teknik analisis data yang digunakan penulis dalam penelitian ini ada empat kriteria, yaitu: kredibilitas, transferabilitas, dependabilitas, dan konfirmabilitas

\section{Lokasi Penelitian}

Penelitian ini dilaksanakan di Kantor Palayanan Pajak Pratama Bekasi Barat yang beralamat di M Gold Tower Lantai UG 9,10, Jl.KH.Noer Ali, RT.007/RW.003, Pekayon Jaya, Kecamatan Bekasi Selatan, Kota Bekasi, Jawa Barat, 17148.

\section{HASIL PENELITIAN DAN PEMBAHASAN}

\section{Hasil Penelitian}

Hasil penelitian berisi penjelasan data dan informasi yang telah diperoleh dalam penelitian melalui wawancara kepada pihak yang terkait dalam penelitian ini seperti Fiskus, Akademisi, Informan Ahli dan Wajib Pajak. Dalam melakukan penelitian ini peneliti melakukan wawancara kepada beberapa pihak 
dibawah ini :

Tabel.1 Daftar Informan Yang Peneliti Wawancarai

\begin{tabular}{|c|l|l|}
\hline $\begin{array}{c}\text { No. } \\
\text { Informan }\end{array}$ & \multicolumn{1}{|c|}{ Nama Informan } & \multicolumn{1}{c|}{ Kelompok Informan } \\
\hline 1. & Adi Yahya & $\begin{array}{l}\text { Account representative bagian } \\
\text { Pengawasan dan Konsultasi II } \\
\text { KPP Pratama Bekasi Barat. }\end{array}$ \\
\hline 2. & Anggun & Pelaksana Seksi Pelayanan \\
\hline 3. & Dadang Abdul Mu'ti & Dosen Pajak Institut STIAMI \\
\hline 4. & Bapak Rianto & Wajib Pajak Terdaftar \\
\hline 5. & Ibu Sarah & Wajib Pajak Terdaftar \\
\hline
\end{tabular}

Sumber : Diolah oleh penulis, 2020

Data sekunder yang penulis peroleh dari Seksi Pengolahan Data dan Informasi KPP Pratama Bekasi Barat berupa jumlah wajib pajak terdaftar pada KPP Pratama Bekasi Barat Tahun 2017-2019, Target dan Realisasi Penerimaan Pajak Pada KPP Pratama Bekasi Barat Tahun 2017-2019, dan Target dan Realisasi Wajib Pajak Bayar KJS (Kode Jenis Setor) tertentu Pada KPP Pratama Bekasi Barat Tahun 2017-2019, yang kemudian penulis olah menjadi data tabel di bawah ini:

Tabel.2 Jumlah Wajib Pajak Terdaftar Pada KPP Pratama Bekasi Barat Tahun 2017-2019

\begin{tabular}{|l|c|c|c|}
\hline Jenis WP & $\mathbf{2 0 1 7}$ & $\mathbf{2 0 1 8}$ & $\mathbf{2 0 1 9}$ \\
\hline Badan & 8.870 & 9.530 & 10.254 \\
\hline OP Non Karyawan & 13.966 & 14.951 & 16.470 \\
\hline OP Karyawan & 133.896 & 140.242 & 147.608 \\
\hline
\end{tabular}

Sumber : Seksi Pengolahan Data dan Informasi KPP Pratama Bekasi Barat diolah oleh penulis, 2020

Berdasarkan tabel diatas Jumlah Wajib Pajak pada KPP Pratama Bekasi Barat pada tahun 2017 - 2019 selalu mengalami peningkatan Jumlah Wajib Pajak Terdaftar setiap tahunnya, baik Wajib Pajak Badan, Orang pribadi Non Karyawan, maupun Orang Pribadi karyawan. Namun terjadinya peningkatan jumlah Wajib Pajak terdaftar tidak menjamin akan terjadinya peningkatan penerimaan pajak.

Tabel .3 Target dan Realisasi Penerimaan Pajak Pada KPP Pratama Bekasi BaratTahun 2017-2019

\begin{tabular}{|c|c|c|}
\hline Tahun & \multicolumn{1}{|c|}{ Target } & \multicolumn{1}{c|}{ Realisasi } \\
\hline 2017 & Rp. 1.169 .435 .499 .000 & Rp. 1.110 .555 .403 .156 \\
\hline 2018 & Rp. 1.331 .140 .230 .000 & Rp. 1.239 .895 .723 .343 \\
\hline 2019 & Rp. 1.270 .884 .947 .000 & Rp. 1.233 .407 .823 .413 \\
\hline
\end{tabular}

Sumber : Seksi Pengolahan Data dan Informasi KPP Pratama Bekasi Barat diolah oleh penulis, 2020

Berdasarkan tabel diatas target dan realisasi penerimaan pajak yang ditetapkan setiap tahun nya terus meningkat. Kecuali pada tahun 2019 KPP Pratama Bekasi Barat menurunkan target penerimaan pajak namun tetap saja realisasi penerimaan pajak pada tahun 2019 tidak mencapai target. Maka Selama 3 tahun terakhir realisasi penerimaan pajak belum dapat mencapai target yang telah ditentukan. 
Tabel.4 Target dan Realisasi Wajib Pajak Bayar KJS (Kode Jenis Setor) tertentu Pada KPP Pratama Bekasi Barat Tahun 2017-2019

\begin{tabular}{|c|c|c|c|}
\hline Uraian/Tahun & $\mathbf{2 0 1 7}$ & $\mathbf{2 0 1 8}$ & $\mathbf{2 0 1 9}$ \\
\hline $\begin{array}{c}\text { Target WP Bayar KJS } \\
\text { Tertentu }\end{array}$ & 4.971 & 6.555 & 6.931 \\
\hline $\begin{array}{c}\text { Realisasi WP Bayar } \\
\text { KJS Tertentu }\end{array}$ & 3.589 & 4.169 & 4.669 \\
\hline
\end{tabular}

Sumber : Seksi Pengolahan Data dan Informasi KPP Pratama Bekasi Barat diolah oleh penulis, 2020

Berdasarkan tabel diatas Realisasi Kepatuhan Wajib Pajak Bayar KJS (Kode Jenis Setor) tertentu pada KPP Pratama Bekasi Barat tahun 2017-2019 mengalami peningkatan setiap tahunnya namun tidak mencapai target yang telah ditentukan. Faktor yang menyebabkan penerimaan pajak tidak mencapai target karena wajib pajak tidak mengetahui wujud konkret imbalan dari uang yang dikeluarkan untuk membayar pajak. Dan masih rendahnya tingkat kepercayaan wajib pajak sehingga adanya persepsi bahwa pajak yang dibayarkan pasti disalahgunakan.

\section{Pembahasan}

Setelah melakukan penelitian, peneliti melakukan analisis data dan interprestasi pembahasan terhadap data yang telah ditentukan sebagai hasil penelitian dengan menggunakan analisis verbatim yang telah disajikan di atas. Berdasarkan hasil penelitian mengenai Analisis Tax Awareness Dalam Upaya Meningkatkan Kepatuhan Wajib Pajak Di Kantor Pelayanan Pajak Pratama Bekasi Barat adalah sebagai berikut :

\section{a. Bagaimana Tax Awareness (Kesadaran Wajib Pajak) Dalam Upaya Meningkatkan Kepatuhan Wajib Pajak Di Kantor Pelayanan Pajak Pratama Bekasi Barat Periode 2017-2019}

Berdasarkan yang telah dijabarkan pada bab-bab sebelumnya, dalam berhasilnya Tax Awareness (kesadaran wajib pajak) disini, penulis menganalisis dengan teori Rahayu bahwa dalam melakukan analisis Tax Awareness (kesadaran wajib pajak) perlu adanya metode yang tepat dalam mengimplementasikannya dengan baik yaitu : Kesadaran akan fungsi pajak, Kesadaran akan manfaat pajak yang dibayarkan, Kesadaran untuk membayar pajak bukan karena paksaan, dan Kesadaran bahwa pajak diatur undang-undang.

\section{1) Kesadaran Akan Fungsi Pajak}

Berdasarkan analisis verbatim tentang kesadaran akan fungsi pajak bahwa sebagian wajib pajak sudah mengetahui fungsi pajak ialah wajib pajak yang taat dalam melakukan kewajiban perpajakannya dalam hal membayar pajak dan menyadari bahwa pajak sudah sesuai dengan fungsinya. Namun sebagian wajib pajak yang tidak mengetahui fungsi pajak ialah wajib pajak yang tidak taat dalam melakukan kewajiban perpajakannya dalam hal membayar pajak. Karena tidak semua wajib pajak mengetahui apakah fungsi pajak sudah sesuai dengan fungsinya atau tidak, namun secara implementasi atas penggunaan dana dari pajak itu yang harus diawasi dan diperhatikan kembali, dikhawatirkan dana pajak itu diselewengkan untuk hal yang lain bukan untuk pembangunan negara.

\section{2) Kesadaran Akan Manfaat Pajak Yang Dibayarkan}

Berdasarkan analisis verbatim tentang kesadaran akan manfaat pajak yang dibayarkan tidak dapat dirasakan secara langsung, beda saat kita berbelanja, saat berbelanja kita langsung mendapatkan manfaatnya. Kesadaran Wajib Pajak belum baik, kaitannya dengan manfaat pajak yang tidak secara langsung dapat dirasakan manfaatnya oleh Wajib Pajak, maka mereka tidak sepenuhnya menyadari tentang manfaat pajak bagi kehidupan mereka. Dan sebagain wajib pajak belum ada kesadaran bahwa telat nya mereka membayar pajak dapat menghambat pembangunan, yang mereka tonjolkan adalah besarnya denda yang harus diderita akibat keterlambatan melakukan kewajiban perpajakannya. Disini 
ada dua sudut pandang yang tidak fare antara membayar pajak dan terlambat membayar pajak. Hanya saja perlu dibenahi mindset wajib pajak Indonesia terlebih dahulu tentang gimana pentingnya pajak dan apa dampak yang dikasih dari wajib pajak itu ketika membayar pajak dan terlambat membayar pajak.

\section{3) Kesadaran Untuk Membayar Pajak Bukan Karena Paksaan}

Berdasarkan analisis verbatim tentang kesadaran untuk membayar pajak bukan karena paksaan bahwa sebagian wajib pajak membayar pajak karena sukarela dimana DJP membuat mindset masyarakat Indonesia ketika membayar pajak ini merasa bangga dan tidak terbebani dan sebaliknya ketika tidak membayar pajak masyarakat akan merasa malu. Sebagian wajib pajak membayar pajak karena takut akan dikenakan sanksi bahkan wajib pajak membayar pajak karena telah mendapat sanksi terlebih dahulu dimana masyarakat akan memenuhi kebutuhan hidupnya terlebih dahulu baru akan memikirkan yang lain. maka bentuk kepatuhan tersebut bukan karena kesadaran atau kesukarelaan melainkan karena rasa ketakutan atau terpaksa.

\section{4) Kesadaran Bahwa Pajak Diatur Undang-Undang}

Berdasarkan analisis verbatim tentang kesadaran bahwa pajak diatur undang- undang bahwa semua wajib pajak sudah mengetahui bahwa pajak di atur di Undang- Undang karena semua yang berkaitan antara masyarakat dengan pemerintah pasti diatur di Undang-Undang. Namun tidak semua wajib pajak memahami tentang perpajakan, banyak wajib pajak hanya mengetahui peraturan perpajakan tetapi tidak sepenuhnya memahami maksud yang terkandung di dalamnya, sehingga masyarakat cenderung mengabaikan peraturan perpajakan dan melakukan penghindaran pajak.

b. Hambatan Yang Mempengaruhi Tax Awareness (Kesadaran Wajib Pajak) Dalam Upaya Meningkatkan Kepatuhan Wajib Pajak Di Kantor Pelayanan Pajak Pratama Bekasi Barat Periode 2017-2019

Dalam analisis tax awareness (kesadaran wajib pajak) sering ditemukan beberapa hambatan dari masalah-masalah yang muncul. Hambatan-hambatan tersebut bisa dari Wajib Pajak ataupun dari fiskusnya, dari sikap Wajib Pajak ataupun dari segi waktu, hambatan dengan pihak-pihak terkait dan hambatan-hambatan lainnya yang bisa terjadi. Dalam penelitian yang dilakukan, peneliti menemukan hambatan yang di hadapi KPP Pratama Bekasi Barat dalam analisis tax awareness (kesadaran wajib pajak) dalam upaya meningkatkan kepatuhan wajib pajak yaitu banyaknya wajib pajak dalam segi jumlah maupun jenisnya sehingga hal tersebut mempengaruhi pemahaman terkait dengan pajak dan kepatuhan kewajiban perpajakannya. Selanjutnya pada saat mendaftarkan NPWP secara online terkdang data nya tidak relate sesuai dengan dilapangan wajib pajak itu sendiri dan tidak semua wajib pajak mengetahui peraturan mengenai perpajakan terbaru. Kemudian tingkat kesadaran Wajib Pajak untuk memenuhi kewajiban perpajakannya masih rendah, karena mereka masih memiliki persepsi bahwa pajak yang dibayarkan pasti disalahgunakan. Selanjutnya Kurangnya pemahaman tentang Undang-Undang Perpajakan dan Belum tersampaikannya secara mendalam tentang manfaat pajak bagi pembangunan dan kepentingan warga Negara dikarenakan manfaat pajak tidak dapat dirasakan secara langsung.

c. Upaya Yang Dilakukan Untuk Mengatasi Hambatan Dalam Tax Awareness (Kesadaran Wajib Pajak) Dalam Upaya Meningkatkan Kepatuhan Wajib Pajak Di Kantor Pelayanan Pajak Pratama Bekasi Barat Periode 2017-2019

Dalam analisis tax awareness (kesadaran wajib pajak) ada beberapa upaya yang dilakukan dari kendala yang terjadi. Upaya tersebut bisa dari wajib pajak ataupun dari akademisi dan fiskus. Berdasarkan hasil penelitian terdapat upaya yang perlu dilakukan KPP Pratama Bekasi Barat adalah sebagai berikut:

1) Melakukan sosialisasi dan edukasi kepada wajib pajak secara rutin agar dapat mengubah mindset wajib pajak yang awalnya wajib pajak tidak sadar dengan pajak menjadi sangat sadar dan peduli dengan pajak sehingga wajib pajak merasa bangga ketika membayar pajak dan merasa malu jika tidak membayar pajak.

2) Melakukan himbauan kepada WP untuk menyampaikan kewajiban perpajakannya melalui emailblast/sms blast.

3) Membuka saluran pelayanan secara online untuk membantu penyampaian SPT dan membuka pelayanan di Mall untuk membantu penyampaian SPT. 
4) Melakukan kegiatan tax education kepada sekolah-sekolah (SD, SMP, SMA/SMK) serta perguruan tinggi sehingga bisa menanamkan pengetahuan terkait pentingnya pajak sejak di usia dini, dan yang terakhir memberikan informasi terkait dengan kegiatan perpajakan melalui media social (instagram dan facebook KPP Pratama Bekasi Barat).

5) Memasukkan pengantar pajak pada kurikulum SLTP dan SLTA sehingga lebih dini mengetahui pengertian tentang pajak. Dan yang terakhir perlu adanya pendekatan langsung kepada Wajib Pajak dengan melakukan pendekatan tatap muka langsung sehingga informasi perpajakan yang diberikan dapat tersampikan dengan baik oleh Wajib Pajak.

\section{PENUTUP}

\section{Kesimpulan}

Berdasarkan hasil penelitian, pembahasan, dan interpretasi yang telah diuraikan pada bab- bab sebelumnya, serta dengan mengacu pada beberapa teori dan hasil penelitian sebelumnya, maka peneliti dapat menarik kesimpulan mengenai Analisis Tax Awareness (Kesadaran Wajib pajak) Dalam Upaya Meningkatkan Kepatuhan Wajib Pajak Di Kantor Pelayanan Pajak Pratama Bekasi Barat sebagai berikut :

a. Tax Awareness (Kesadaran Wajib pajak) di KPP Pratama Bekasi Barat jika diukur dengan teori Tax Awareness (Kesadaran Wajib Pajak) berdasarkan teori Rahayu belum dapat dikatakan berhasil. Jika dilihat realisasi penerimaan pajak di KPP Pratama Bekasi Barat pada tahun 2019 belum dapat mencapai target dengan presentase 97,05\%. Walaupun pada tahun 2019 sudah menurunkan target penerimaan pajak dari tahun sebelumnya tetapi tetap belum mencapai target yang telah ditentukan. Begitu pula dengan kepatuhan wajib pajak bayar KJS (Kode Jenis Setor) tertentu pada tahun 2017- 2019 mengalami peningkatan, namun setiap tahunnya tidak mencapai target yang telah ditentukan.

b. Faktor penghambat Tax Awareness (Kesadaran Wajib Pajak) di Kantor Pelayanan Pajak Pratama Bekasi Barat adalah banyaknya wajib pajak dalam segi jumlah maupun jenisnya sehingga hal tersebut mempengaruhi pemahaman terkait dengan pajak dan kepatuhan kewajiban perpajakannya. Selain itu tingkat kesadaran Wajib Pajak untuk memenuhi kewajiban perpajakannya masih rendah, karena manfaat pajak tidak dapat dirasakan secara langsung dan wajib pajak masih memiliki presepsi bahwa pajak yang dibayarkan pasti diselewengkan.

c. Upaya yang dilakukan untuk mengatasi hambatan yang terjadi dalam Tax Awareness (Kesadaran Wajib Pajak) di Kantor Pelayanan Pajak Pratama Bekasi Barat adalah melakukan sosialisasi kepada wajib pajak secara rutin agar dapat mengubah mindset wajib pajak yang awalnya wajib pajak tidak sadar dengan pajak menjadi sangat sadar dan peduli dengan pajak sehingga wajib pajak merasa bangga ketika membayar pajak dan merasa malu jika tidak membayar pajak. Dan melakakukan edukasi kepada wajib pajak tentang alokasi pajak yang dibayarkan agar persepsi wajib pajak dapat berubah bahwa dana pajak tidak disalahgunakan.

\section{Saran}

Setelah dilakukannya penelitian, untuk perkembangan lebih lanjut maka peneliti memberikan saran yang bermanfaat atas analisis Tax Awareness (Kesadaran Wajib Pajak) dalam upaya meningkatkan kepatuhan Wajib Pajak di KPP Pratama Bekasi Barat adalah sebagai berikut :

a. Meningkatkan citra Good Governance yang dapat menimbulkan adanya rasa saling percaya antara pemerintah dan masyarakat wajib pajak, sehingga kegiatan pembayaran pajak akan menjadi sebuah kebutuhan dan kerelaan, bukan suatu kewajiban. Dengan demikian tercipta pola hubungan antara negara dan masyarakat dalam memenuhi hak dan kewajiban yang dilandasi dengan rasa saling percaya.

b. Memasukkan mata pelajaran perpajakan dalam kurikulum pendidikan, dari mulai pendidikan dasar, menengah, dan tinggi, sehingga lebih dini mengetahui tentang pajak. Disamping itu generasi muda berpotensi sangat besar untuk dibentuk agar dimasa depan mereka dapat menjadi generasi penerus yang taat dan patuh dalam melaksanakan kewajiban perpajakannya. Semakin tinggi tingkat kesadaran wajib pajak maka kepatuhan wajib pajak dalam melaksanakan kewajiban perpajakannya yaitu membayar pajak akan meningkat dan penerimaan pajak akan tercapai.

c. Untuk dapat meningkatkan kesadaran wajib pajak dalam meningkatkan kepatuhan wajib pajak, 
sebaiknya KPP Pratama Bekasi Barat mengadakan sosialisasi kepada masyarakat secara rutin. Sosialisasi yang dilakukan dapat berupa seminar atau webinar mengenai pentingnya membayar pajak, manfaat pajak yang diperoleh dari membayar pajak, dan fungsi pajak untuk pembangunan negara. Selain itu sosialisasi yang dapat menambah pengetahuan dan pemahaman dari wajib pajak terhadap peraturan perpajakan dan dapat membantu meningkatkan sikap sadar membayar pajak agar masyarakat mau untuk membayar pajak. Semakin baik kesadaran wajib pajak yang diterapkan, maka semakin baik pula wajib pajak yang patuh dalam memenuhi kewajibannya perpajakannya.

\section{REFERENSI}

\section{Sumber Buku:}

Burton, B, Ilyas . (2013). Hukum Pajak, Edisi 6.Jakarta: Salemba Empat

David, Fred, R. 2011. Manajemen Strategi (Strategic Management), Edisi 12. Jakarta: Salemba Empat

Djamal, M. 2015. Paradigma Penelitian Kualitatif. Yogyakarta: Pustaka Pelajar

Harjo, Dwikora. 2013. Perpajakan Indonesia Sebagai Materi Perkuliahan di Perguruan Tinggi. Jakarta : Mitra Wacana Media.

2019. Perpajakan Indonesia Sebagai Materi Perkuliahan di Perguruan Tinggi. Edisi 2. Jakarta : Mitra Wacana Media.

Mardiasmo. 2016. Perpajakan Edisi Revisi. Yogyakarta: PenerbitAndi.

2018. Perpajakan Edisi Terbaru 2018. Yogyakarta: C.V Andi Offset. Pasolong, Harbani. 2010. Teori Administrasi Publik. Bandung: Alfabeta.

Pohan. Chairil Anwar. 2014. Pembahasan Komperehesif Perpajakan Indonesia Teori dan Kasus. Jakarta: Mitra Wacana Media.

Rahayu, Siti Kurnia.. 2010. Perpajakan Indonesia: Konsep dan Aspek Formal. Yogyakarta: Graha Ilmu.

2013. Perpajakan Indonesia: Konsep \& Aspek Formal. Yogyakarta: Graha Ilmu

Rahman, Abdul. 2010. Paduan Pelaksanaan Administrasi Perpajakan untuk Karyawan, Pelaku Bisnis dan perusahaan. Bandung: Nuansa.

Rangkuti, Freddy. 2014. Analisis SWOT: Teknik Membedah Kasus Bisnis. Jakarta: PT. Gramedia Pustaka Utama.

Resmi, Siti. 2017. Perpajakan Teori dan Kasus. Edisi 10. Jakarta: Salemba Empat.

Rony, Zahara Tussoleha. 2017. Siap Fokus, Siap Menulis Skripsi, Tesis, Disertasi: Jurus mudah gunakan metode kualitatif tipe studi kasus. Jakarta: Pusat Studi Sumber Daya Manusia.

Rumelt, P. Richard. 2011. Good Strategy/Bad Strategy: the difference and why it matters. Jakarta. Kepustakaan Populer Gramedia

Sugiyono. 2014. Metode Penelitian Kuantitatif, Kualitatif, dan R\&D. Bandung : Alfabeta

2017. Metode Penelitian Kuantitatif, Kualitatif, dan R\&D. hlm 9, 13- 14. Bandung: Alfabeta.

Suherman.2011.Desain Pembelajaran Kewirausahaan. Bandung : Alffabeta

Sujarweni, V. Wiratna. 2014. Metode Penelitian: Lengkap, Praktis, dan Mudah Dipahami. Yogyakarta: Pustaka Baru Press.

Suryadi, Didih. 2011. Promosi Efektif “Menggugah Minat \& Loyalitas Pelanggan”. Jakarta: PT. Suka Buku

Syafiie, Inu Kencana. 2010. Ilmu administrasi Publik. Jakarta: Rineka Cipta.

\section{Jurnal :}

Annisatul Khoeriyah, Chairil Anwar Pohan. 2019. Pelaksanaan Sistem E-Filing Dalam Rangka Meningkatkan Kepatuhan Wajib Pajak Orang Pribadi Pada Kantor Pelayanan Pajak Pratama Jakarta Tanah Abang Tiga Tahun 2018. Jakarta. Institut Ilmu Sosial Dan Manajemen STIAMI. 
http://jurnal.akptahuna.ac.id/index.php/ekbank/article/download/21/ 21 Diakses pada 14 Februari 2020

Daniel Ortage, Carlos Scartascini .2015. “A Field Experiment on Delivery Methods for Increasing Tax Compliance". CAF-Working paper $\mathrm{N}$ https://www.semanticscholar.org/.../A-Field-Experiment- Diakses pada tanggal 14 Febrruari 2020

Edward E. Marandu, Christian J. Mbekomize, Alexander N. Ifezue. 2015. "Determinants of Tax Compliance : A Review of Factors and Conceptualizations". International Journal Of Economics and Finance; Vol.7, No. 9; 2015 http://www.ccsenet.org/journal/index.php/ijef/article/view/49585 Diakses pada tanggal 14 Febrruari 2020

Fitria Dona.2017. Pengaruh Kesadaran Wajib Pajak, Pengetahuan dan Pemahaman Perpajakan Terhadap Kepatuhan Wajib Pajak. Jakarta. Universitas Indraprasta PGRI. https://journal.lppmunindra.ac.id/index.php/JABE/article/view/1905/1485 Diakses pada tanggal 5 Desember 2019

Hidayatullah Amir, Karnedi Nahdah Fistra. 2019. Pengaruh Kesadaran Perpajakan, Sanksi Pajak, Dan Tax Amnesty Terhadap Kepatuhan Wajib Pajak Orang Pribadi.Universitas Ahmad Dahlan. https://publikasi.mercubuana.ac.id/index.php/profita/article/view/profita.2019.v12.01.001/pdf Diakses pada 14 Februari 2020

Halimatusyadiah, Siahaan Stefani. 2018. Pengaruh Kesadaran Perpajakan, Sosialisasi Perpajakan, Pelayanan Fiskus, Dan Sanksi Perpajakan Terhadap Kepatuhan Wajib Pajak Orang Pribadi (Studi Pada Kantor Pelayanan Pajak Bengkulu). Bengkulu. Universitas Bengkulu. file:///C:/Users/USERR/Downloads/758915537-1-SM.pdf Diakses pada tanggal 5 Desember 2019

Lydiana.2018.Pengaruh Kesadaran Wajib Pajak, Pengetahuan Pajak, Dan Sanksi Pajak Terhadap Kepatuhan Wajib Pajak Orang Pribadi Di KPP Pratama Surabaya Gubeg.Surabaya.Universitas Sam Ratulangi. https://journal.ubaya.ac.id/index.php/jimus/article/view/1131 Diakses pada 14 Februari 2020

Nur Muhammad. 2018. Pengaruh Kesadaran Wajib Pajak Terhadap Kepatuhan Wajib Pajak Di KPP Pratama Makassar Utara. Makassar. Universitas Muslim Indonesia. https://journal.unismuh.ac.id/index.php/Perspektif/article/view/1667/1355 Diakses pada tanggal 5 Desember 2019

Purwanti. Ninik Endang. Mustakim. Igam. Mingriani . 2018. Strategi Meningkatkan Kepatuhan Wajib Pajak Di Kantor Pelayanan Pajak Pratama Kendari. Sulawesi Tenggara. Unversitas Halu Oleo Kendari http://ojs.uho.ac.id/index.php/BUSSINESUHO/article/download/9444/6663 Diakses pada 5 Desember 2019

Supadmi Ni Luh, Agung darma Wicaksana. 2019. Pengaruh Kesadaran Wajib Pajak, Pelayanan Fiskus, Sanksi Pajak, dan Tax Amnesty Pada Kepatuhan Wajib Pajak Orang Pribadi. Bali. Universitas Udayana. https://www.researchgate.net/publication/334276586_Pengaruh_Kesadaran_WP_Pelayanan_Fiskus_Sank si_Pajak_dan_Tax_Amnesty_Pada_Kepatuhan_WPOP/link/5d209a50458515c11c1610a6/download Diakses pada tanggal 5 Desember 2019

\section{Peraturan:}

Undang-Undang No 16 Tahun 2009 Tentang Ketentuan Umum dan Tata Cara Perpajakan. 